\title{
THE ELEVATED TEMPERATURE AND GAS COMPONENT WITHIN AN OPERATING SEMI-AEROBIC LANDFILL
}

\author{
Vu Quang Huy *, Yukihiro Kohata and Hideki Yoshida
}

Course of Civil Engineering, Muroran Institute of Technology, 27-1 Mizumoto-cho, Muroran, Hokkaido, 050-8585, Japan
Article Info:
Received:
19 October 2019
Revised:
17 February 2020
Accepted:
11 March 2020
Available online:
8 May 2020
Keywords:
Semi-aerobic landfill
Aerobization
Landfill gas temperature
Landfill gas component

\begin{abstract}
The semi-aerobic landfill concept, which is based on passive aeration, is the compulsory standard for planning new landfill projects in Japan. The semi-aerobic landfill concept is also applied in several other countries because of its low construction and operating costs. The landfill gas (LFG) component and the LFG temperature are the main indicators of the aerobization of semi-aerobic landfills. Analysis of LFG, its concentration, and its temperature can be easily carried out on-site to evaluate the passive aeration of an operating semi-aerobic landfill. Therefore, this study observed LFG temperatures and LFG components to assess the partial aerobization within an operating semi-aerobic landfill. The observational data revealed that the methane $\left(\mathrm{CH}_{4}\right)$ gas concentration of most of the main LFG venting pipes (VPs) was below $15 \%$. The aerobic condition happened effectively surrounding the main LFGVP M2 because over the observation period, the ratio of $\mathrm{CH}_{4}$ to $\mathrm{CO}_{2}$ was less than 1.0. The highest gas temperature was above $60^{\circ} \mathrm{C}$ within the main LFGVP M2, and there was a trend of high temperatures above $40^{\circ} \mathrm{C}$ for more than 5 years before the temperature declined to $20^{\circ} \mathrm{C}$ in the most recent observation. The high LFG temperatures were recorded in the winter months due to the buoyancy effect. High temperature and the $\mathrm{CH}_{4} / \mathrm{CO}_{2}$ ratio less than 1.0 potentially representing good indicators showed that aerobic decomposition is becoming dominant. The study showed clearly that the aerobic biodegradation performance in this semi-aerobic landfill is extremely good.
\end{abstract}

\section{INTRODUCTION}

Landfilling technology continues to be one of the main methods used in future modern municipal solid waste (MSW) strategies (Cossu, 2012), particularly in developing countries, because of low construction and operation costs as compared to other technologies. It is a necessary and unavoidable step in closing the material cycle (Cossu, 2009; Cossu et al., 2016). At present, there are 4 types of main landfilling concepts: anaerobic, aerobic, semi-aerobic, and hybrid. Each type has its own advantages and disadvantages. The choice of a specific type depends on many factors (i.e., cost, regulations, climate, waste characteristics). Also, the goals of waste treatment (i.e., energy recovery, increasing the waste stabilization) play a role in landfill type selection (Grossule et al., 2018). One of the biggest challenges of landfilling technology is to maintain the performance of a landfill as its initial design purposes to minimize the risks to the surrounding environment. A good design, together with an appropriate operation mode, will reduce significantly the negative impacts on the environment and public health (Hrad et al., 2013; Stegmann and Ritzkowski, 2007).
The rapid development of science and technology during the last decades helped researchers to propose the "sustainable landfill" concept (Antonis and Haris, 2009; Cossu, 2005) with the aim of (1) reducing waste volume, (2) accelerating the stabilization of waste, (3) minimizing landfill gas production which leads to greenhouse effect, (4) rapid biogas production, and (5) decreasing the leachate organic load. In 2002, a special Task Group of International Waste Working Group (IWWG) was established to achieve these targets through a project named "Landfill Aeration". By means of the research projects all over the world, researchers realized that aerobic conditions process faster the waste degradation and reduce more significantly emissions than the anaerobic environment. Besides, the "Landfill Aeration" project has paved the way for the recovery of valuable resources through landfill mining. Therefore, in recent years, in situ landfill aeration projects have received much attention. It has been considered as a useful tool for the sustainable conversion of conventional anaerobic landfills into a biologically stabilized state. It has also shown a minimized emission potential (Ritzkowski and Stegmann, 2012). 
Many years ago, in some places in America, Europe and Japan the air and moisture have been added into a landfill to create the optimized aerobic conditions which help aerobic microorganisms degrade biodegradable organic matter. The concept of semi-aerobic landfill might be the oldest method for landfill aeration.

The semi-aerobic landfill concept is based on passive aeration. This concept was developed in 1975 by researchers at Fukuoka University, Japan, when it was given the name semi-aerobic landfill. In semi-aerobic landfills, waste is aerated naturally by atmospheric air via a network of horizontal leachate collection pipes (LCPS) connected to vertical landfill gas (LFG) venting pipes (VPs). The outlet of the main LCP in the leachate pond is always open. Air is drawn into the main LCP due to a buoyancy effect, and the LFG is discharged into the atmosphere (Matsufuji and Tachifuji, 2007). Because of both the limited strength of the passive aeration induced by natural ventilation and anaerobic zones remaining inside the semi-aerobic landfill, the process of biological stabilization occurs more slowly in semi-aerobic landfill than that in actively aerated landfill. For this reason, semi-aerobic landfill has partial aeration around the wells and pipes.

Although numerous studies have focused on the semi-aerobic landfill concept (Ahmadifar et al., 2016; Cossu et al., 2016; Grossule and Lavagnolo, 2017; Hanashima et al., 1981; Hirata et al., 2012; Huang et al., 2008; Matsuto et al., 2015; Morello et al., 2017; Ritzkowski et al., 2006; Shimaoka et al., 2000; Theng et al., 2005; Wu et al., 2017; Yang et al., 2012), most of them were conducted using a lysimeter either in a laboratory or at pilot scale. Those demonstrated significant achievements of the semi-aerobic landfill concept, including (1) accelerating the biodegradation of organic matter, (2) improving leachate quality, (3) reducing methane $\left(\mathrm{CH}_{4}\right)$ gas emission, and (4) entailing lower construction and maintenance costs (Ishigaki et al., 2011). The current study has been carried out over many years to monitor and evaluate the aerobization within a fullscale operational semi-aerobic landfill based on measurements of the LFG temperature and concentration.

LFG temperature is regarded as a good index for assessing the decomposition of biodegradable waste. Both aerobic and anaerobic decomposition processes generate heat (see Equations 1 and 2). Rees (1980) measured a temperature range of $40^{\circ} \mathrm{C}-45^{\circ} \mathrm{C}$ in a waste layer that was $4 \mathrm{~m}$ thick. High temperatures, in the range of $60^{\circ} \mathrm{C}-90^{\circ} \mathrm{C}$, have also been measured in other parts of the world (Bouazza et al., 2011; Yesiller et al., 2015, 2011; Yoshida and Rowe, 2003). Moreover, several studies have been aimed at determining the heat generation value through theoretical analyses of biochemical decomposition of waste. Pirt (1978) and Rees (1980) reported a heat generation value of $632 \mathrm{~kJ} / \mathrm{kg}$ glucose for anaerobic digestion. Cooney et al. (1969) reported a heat generation value of approximately $110 \mathrm{kcal} / \mathrm{mol}$ oxygen $\left(\mathrm{O}_{2}\right)(15,400 \mathrm{~kJ} / \mathrm{kg}$ glucose $)$ for aerobic digestion. Thus, it is clear that aerobic decomposition generates a larger amount of heat from waste decomposition than does anaerobic decomposition.

In practice, LFG is considered to be a mixture of the gases $\mathrm{CH}_{4}$, carbon dioxide $\left(\mathrm{CO}_{2}\right), \mathrm{O}_{2}$, and nitrogen $\left(\mathrm{N}_{2}\right)$. LFG is composed $45 \%$ to $60 \%$ methane and $40 \%$ to $60 \%$ carbon dioxide (ATSDR, 2001). In conventional sanitary anaerobic landfills operating under normal conditions, the ratio is typically from 0.8 to 1.4 (Benson, 2017). Theoretically, if the ratio of $\mathrm{CH}_{4}$ to $\mathrm{CO}_{2}$ is either greater than or equal to 1 (from Equation 1), the anaerobic condition predominates (Barlaz et al., 2010; Jafari et al., 2017; Martin et al., 2013). Thus, it can be derived that if the $\mathrm{CH}_{4} / \mathrm{CO}_{2}$ ratio is less than 0.8 , anaerobic and aerobic conditions are coexisting simultaneously within the landfill. Matsufuji et al. (1996) created a semi-aerobic landfill model in a lysimeter and found the $\mathrm{CH}_{4} / \mathrm{CO}_{2}$ ratio to be 1.0. IPCC (2006) calculated the ratio to be 0.33 by using default values. Kim et al. (2010) measured the ratio at 1.0 in a closed landfill site that had been undergoing remediation to accelerate landfill stabilization through installing numerous passive LFGVPs that were not connected to the LCPs. Yang et al. (2012) found the $\mathrm{CH}_{4} / \mathrm{CO}_{2}$ ratios for anaerobic landfills and semi-aerobic landfills to be 1.9 and 0.8 , respectively. Zhang and Matsuto (2013) reported a $\mathrm{CH}_{4} / \mathrm{CO}_{2}$ ratio between 1.0 and 1.5 for a semi-aerobic landfill site that was not being operated correctly. Jeong et al. (2015) measured LFG from VPs in five semi-aerobic landfills in South Korea. However, the ends of LCPs in all five landfill sites were closed, and the $\mathrm{CH}_{4} / \mathrm{CO}_{2}$ ratio ranged from 1.08 to 1.46 , averaging 1.30. Thus, a $\mathrm{CH}_{4} /$ $\mathrm{CO}_{2}$ ratio below 1.5 might be an indicator of landfills with a semi-aerobic design. The reactions in aerobic and anaerobic decomposing processes are shown in a simplified way as follows:

Anaerobic condition: $\mathrm{C}_{6} \mathrm{H}_{12} \mathrm{O}_{6} \rightarrow 3 \mathrm{CO}_{2}+3 \mathrm{CH}_{4}+\mathrm{Heat}$ Aerobic condition: $\mathrm{C}_{6} \mathrm{H}_{12} \mathrm{O}_{6}+6 \mathrm{O}_{2} \rightarrow 6 \mathrm{CO}_{2}+6 \mathrm{H}_{2} \mathrm{O}+$ Heat

The $\mathrm{CH}_{4} / \mathrm{CO}_{2}$ ratio is regarded as an indicator for evaluating the proportions of anaerobic decomposition and aerobic decomposition. Semi-aerobic landfill is a partial aerobization system because passive aeration works only around LFGVPs and LCPs, and there is limited penetration of $\mathrm{O}_{2}$ into waste mass.

\section{DESCRIPTION OF THE SURVEYED LAND- FILL}

\subsection{General description}

This semi-aerobic landfill site is located in the northern part of Hokkaido, Japan (Figure 1). It has been designed following the canyon/depression method, and the waste is filled in multiple lifts (sandwiched method). The area of the landfill is $12.3 \mathrm{ha}$, and its volume is expected to reach $1,840,000 \mathrm{~m}^{3}$ over a 27-year period (2003-2030). Each waste type, such as mixed waste, incombustible waste, bottom ash, and fly ash, is placed into the site in different lifts. The operation began in 2003 and is expected to proceed until 2030.

The overall landfill design involves the installation of 73 LFGVPs, classified into three different types, including 9 main gas VPs (M), 59 branch gas VPs (B), and 5 monitoring gas VPs $(\mathrm{MH})$.

Figure 2 shows a typical landfill gas venting pipe in the landfill site. The LFGVP arrangement consists of a $200 \mathrm{~mm}$ high-density polyethylene pipe surrounded by a vertical 


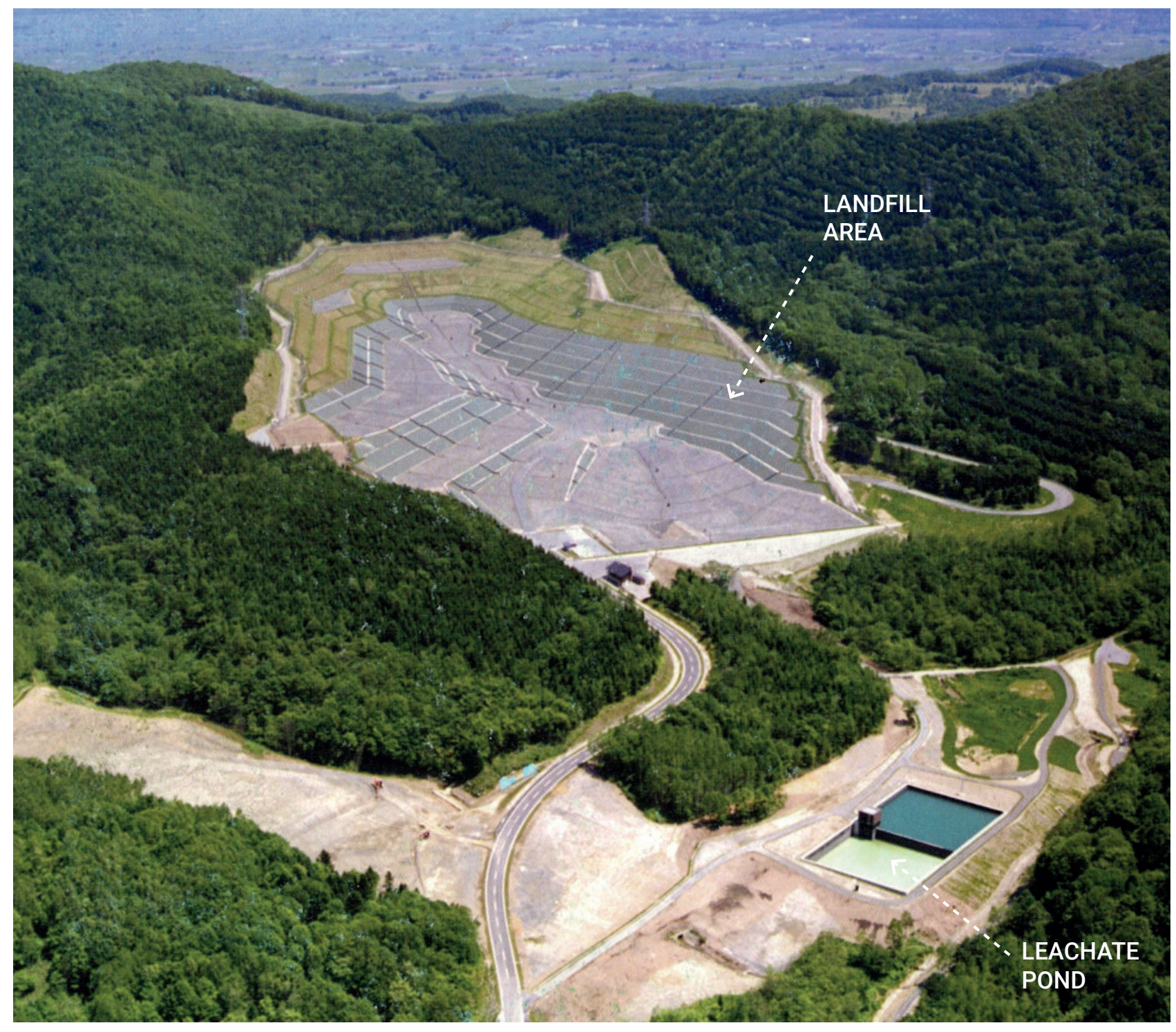

FIGURE 1: Aerial view of the operating semi-aerobic landfill in the northern part of Hokkaido, Japan (in 2003).

gravel layer measuring $1,200 \times 1,000 \mathrm{~mm}$. The VP is perforated along its length with small holes measuring 5-10 $\mathrm{mm}$ in diameter. The average diameter of the gravel (stone) is $15-20 \mathrm{~cm}$. Wire netting is used to support and embed the vertical gravel layer. The purpose of surrounding the VP with this vertical gravel layer is to (1) protect the VP from deformation due to waste compaction and other external forces, (2) reduce clogging of the perforations on the body of the VP, (3) enable the leachate head to quickly, and (4) create another pathway for ambient air to penetrate waste layers.

Apart from the monitoring LFGVPs, which are not connected to the LCP network, all the LFGVPs (e.g., main LFGVPs and branch LFGVPs) are connected to the LCPs to take the air flow into the waste layers. Currently, 53 of 73 LFGVPs have been installed, including 9 main LFGVPs, 39 branch LFGVPs, and 5 monitoring LFGVPs (Figure 3). The unique structure of the semi-aerobic landfill generates passive aeration because its mechanism is based entirely on the buoyancy effect resulting from the temperature differ- ence between the waste mass and the outside air. Thus, a negative pressure siphoning effect is created to draw air into the pipes, and air penetrates the waste mass (Matsufuji and Tachifuji, 2007).

The leachate is collected via an LCP network at the bottom of the landfill and is conveyed to the leachate pond (Figure 1). The diameters of the main LCP and branch LCP are 700 and $400 \mathrm{~mm}$, respectively. The average leachate discharge is $600 \mathrm{~m}^{3} /$ day, and the volume of the leachate pond is $12,700 \mathrm{~m}^{3}$. As for the water quality of the leachate, the suspended solids' concentration is less than $890 \mathrm{mg} / \mathrm{L}$, and the biochemical $\mathrm{O}_{2}$ demand is less than $1,900 \mathrm{mg} / \mathrm{L}$. As mentioned above, in addition to collecting leachate, LCPs convey air into the waste layers. Therefore, the main end of an LCP is always open to the atmosphere.

To date, 53 LFGVPs have been installed in the landfill site. Some of these LFGVPs were built when the landfilling began, whereas others have been installed more recently. Currently, the landfill site is divided into two zones: A and B. 


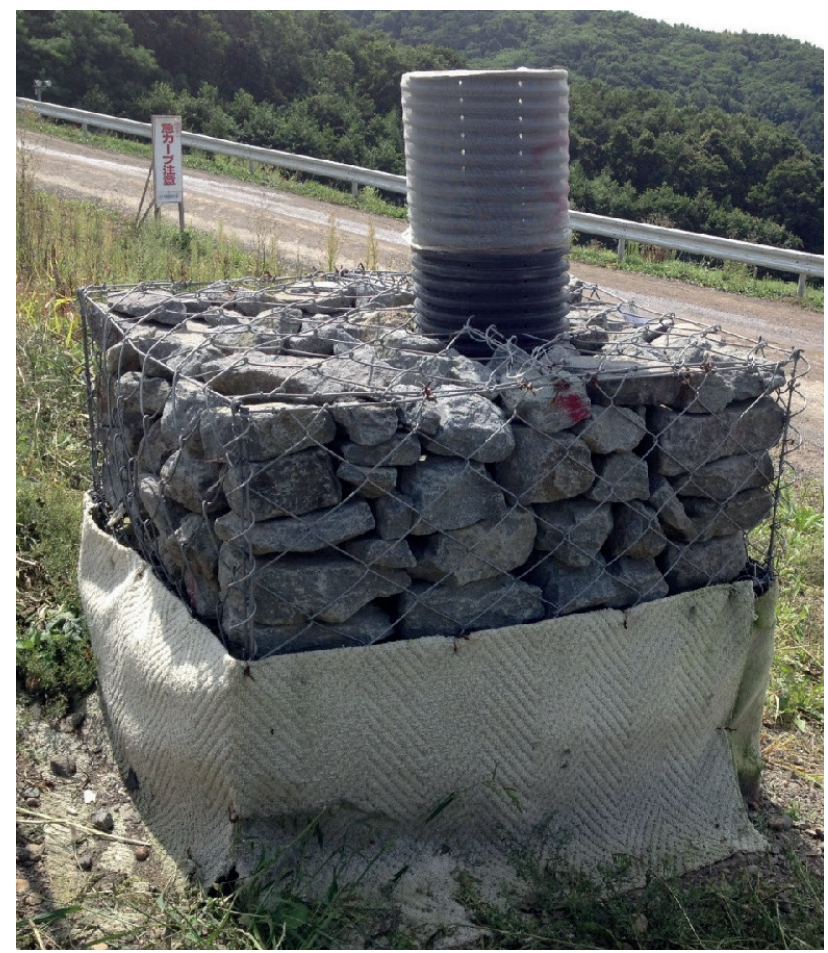

FIGURE 2: A typical landfill gas venting pipe.

In Zone $A$, the landfilling operation was completed in 2010 (Figure 3). By 2014, the volume of waste deposited was $730,550 \mathrm{~m}^{3}$. Zone A contains 28 LFGVPs (4 main LFGVPs, 21 branch LFGVPs, and 3 monitoring LFGVPs), and the waste mass has reached the designed height. The heights of the waste at the main gas VPs M1, M2, M3, and M4 are $17.6,26.6,30.8$, and $33.0 \mathrm{~m}$, respectively. Waste is still being placed in Zone B. Consequently, our analysis focuses on the LFGVPs in Zone A. Figure 4 is the cross-section through some LFGVPs in Zone A and depicts the waste layers buried from before 2005 to 2014 . It should be noted that, before 2005 , the landfill accepted organic waste because the city's incineration plant could not accept all combustible wastes. However, since 2005 , the landfill has accepted only incombustible waste, bottom ash, and fly ash.

Ideally, we should consider all the LFGVPs in Zone A. However, we focus only on measuring the LFG temperature and concentration to identify whether aerobization is occurring within the semi-aerobic landfill. Therefore, the LFGVPs installed in cells containing only bottom ash and fly ash are not considered in this analysis. The monitoring LFGVPs are also not considered in this study because the bottom of these LFGVPs are not connected to the LCPS network and the positions of these LFGVPs are so close to the main LFGVPs or LCPs (i.e., MH2, MH3), the performance of monitoring LFGVPs can be affected by the main LFGVPs.

\section{METHODS}

As shown in Figure 5, the temperature was measured using a thermocouple recorder (Graphtec GL200A, measurement range of thermocouple type $\mathrm{T}$ ), and the gas component was measured using a portable LFG analyzer (Geotech GA5000, Portable Landfill Gas Analyzer). The analyzer was equipped with a pump working at a sampling rate of $550 \mathrm{~mL} / \mathrm{min}$. Typically, a gas sampling tube and a thermom-

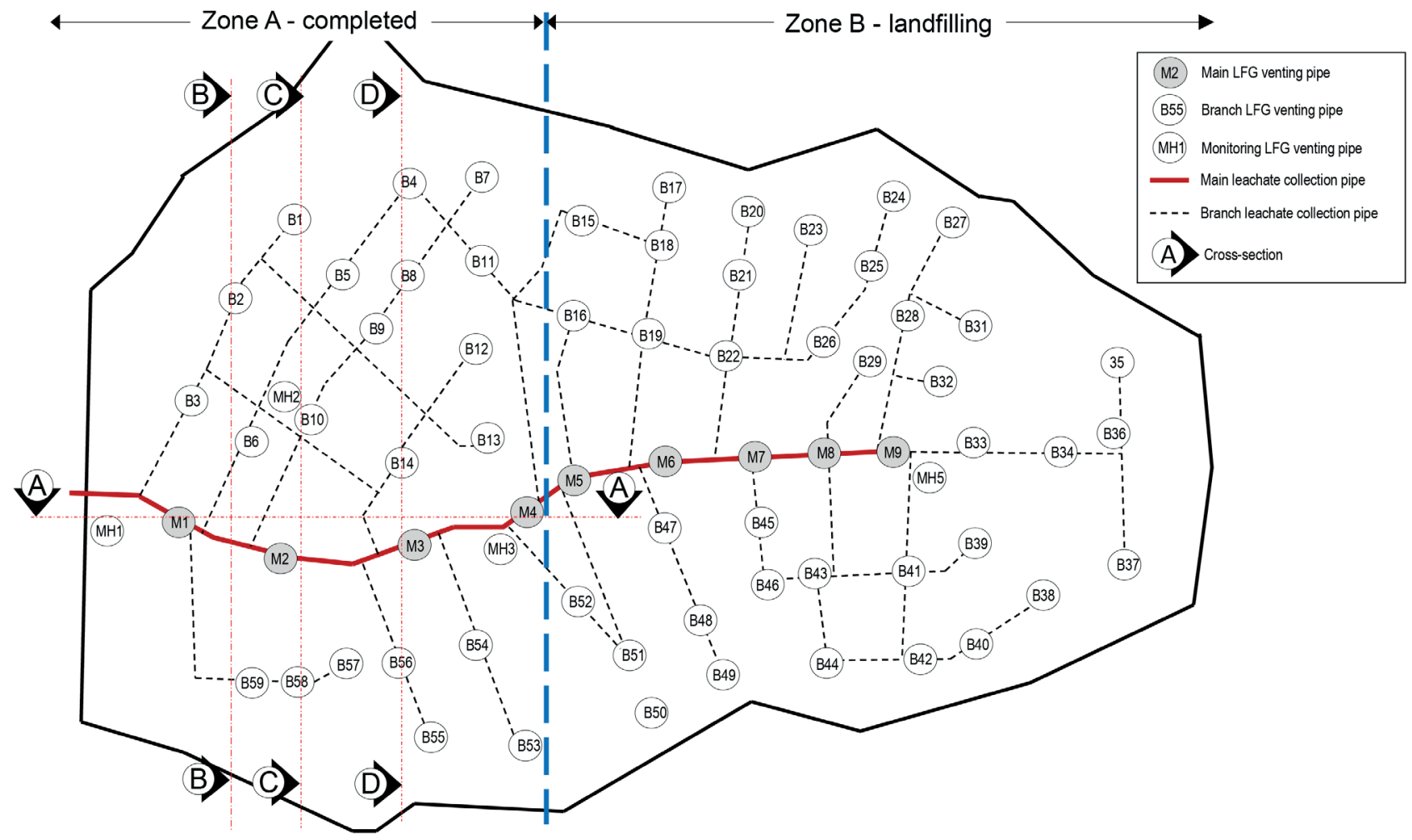

FIGURE 3: The layout of landfill gas venting pipes and the leachate collection system in the surveyed operating semi-aerobic landfill. 


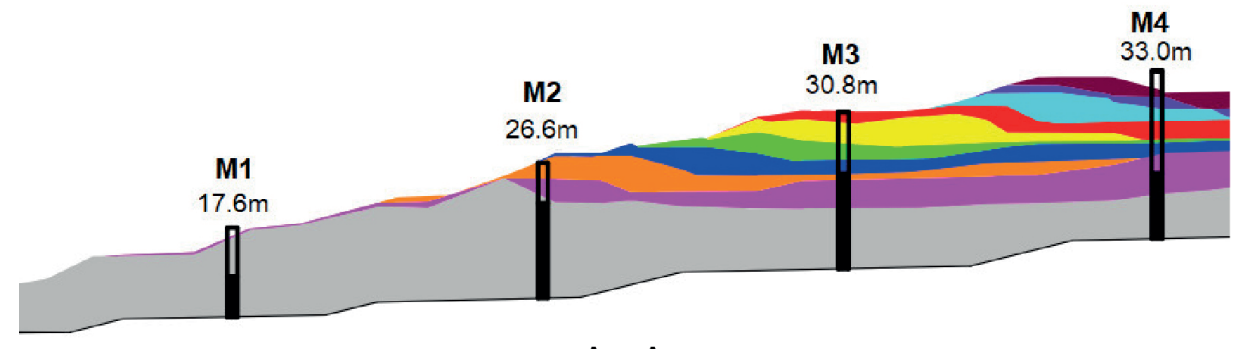

$\underline{A-A}$
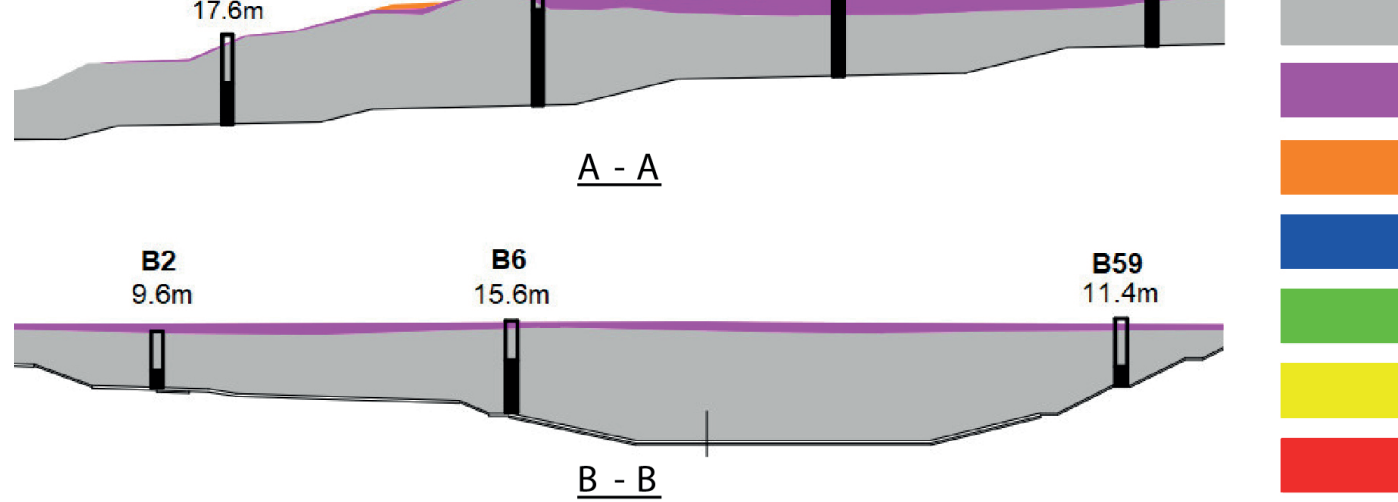

Legend

Before 2005

2005

2006

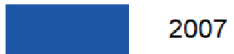

2008

2009

2010
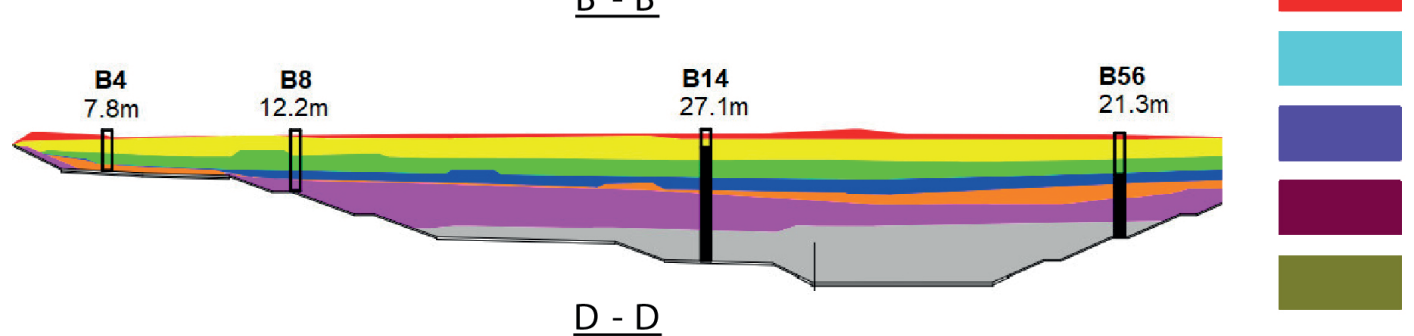

2011

2012

2013

2014

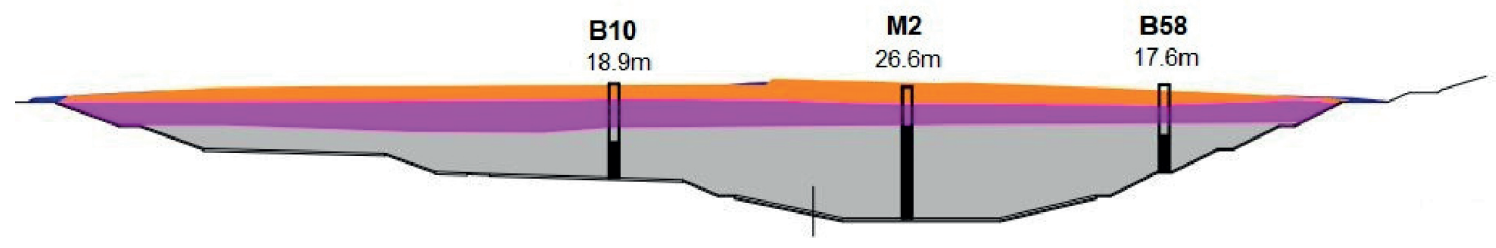

$\underline{C-C}$

FIGURE 4: Cross-section of waste layers through the landfill gas venting pipes.

eter sensor were lowered into LFGVPs to sample the air at 1-m-depth intervals from ground level, and measurements were recorded after $90 \mathrm{~s}$ of sampling. Three different gases - $\mathrm{CH}_{4}, \mathrm{CO}_{2}$, and $\mathrm{O}_{2}$ - were detected occurring simultaneously. The $\mathrm{N}_{2}$ content was determined from the balance of $\mathrm{CH}_{4}, \mathrm{CO}_{2}$, and $\mathrm{O}_{2}$. The accuracy of the measurement after calibration for $\mathrm{CH}_{4}, \mathrm{CO}_{2}$, and $\mathrm{O}_{2}$ was $\pm 0.5 \%, \pm 0.5 \%$, and $\pm 1 \%$, respectively.

Since 2006, gas temperatures and gas component data have been measured in waste layers aged from 2 years to $>11$ years. There are movements of air and gases in the gas wells, and the temperatures measured may not fully represent the adjacent waste mass temperatures at a given measurement location. Nevertheless, due to employing a consistent measurement method, these temperature measurements are representative of temperature trends and variations in temperatures due to changing decomposition conditions in the waste mass and have been used in the analysis presented herein (Yesiller et al., 2011).

Carbon monoxide (CO) concentration was also measured by the Portable Landfill Gas Analyzer. The CO concen- tration was below $30 \mathrm{ppm}$. Therefore, the concern about the potential for subsurface combustion was not significant in this study (FEMA, 2002).

\section{RESULTS AND DISCUSSION}

\subsection{Spatial distribution of LFG}

Figure 6(a) describes the main LFG components, including $\mathrm{CH}_{4}, \mathrm{CO}_{2}, \mathrm{O}_{2}$, and $\mathrm{N}_{2}$, at the exit of LFGVPs surveyed on September 2013. It can be seen that the $\mathrm{CH}_{4}$ concentration at the exit of the surveyed LFGVPs is below $10 \%$ (blue color), apart from the case of the branch LFGVP B10 (24.4\%). Figure $6(\mathrm{~b})$ shows the range of $\mathrm{CH}_{4}$ concentrations at the exits of the surveyed LFGVPs. Here, we rank the $\mathrm{CH}_{4}$ concentration using four colors: green represents a $\mathrm{CH}_{4}$ concentration either less than or equal to $5 \%$, blue represents a concentration greater than $5 \%$ and either less than or equal to $10 \%$, yellow represents a concentration greater than $10 \%$ and either less than or equal to $20 \%$, and red represents a concentration greater than 20\%. Most of the main LFGVPs (M1, M2, M3, and M4) have a $\mathrm{CH}_{4}$ concentration below $10 \%$, whereas the $\mathrm{CH}_{4}$ concentration of 


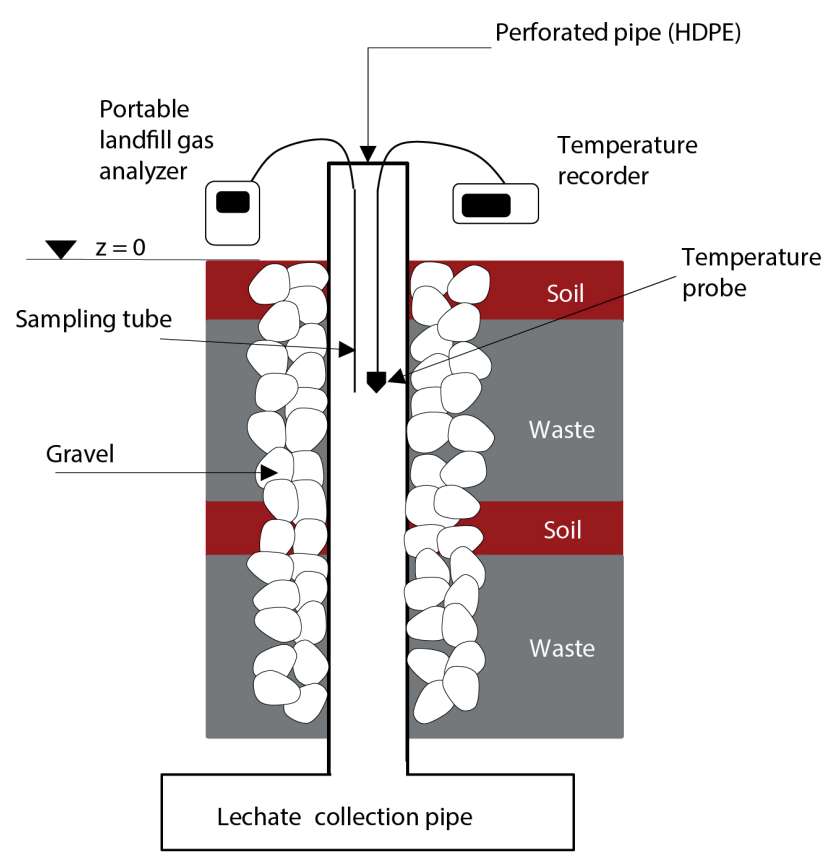

FIGURE 5: LFG temperature and LFG component sampling.

branch LFGVPs ranges from 1.4\% (B12) to $24.4 \%$ (B10). The ranking map of $\mathrm{CH}_{4}$ concentration [Figure 6(b)] shows that most of the LFGVPs with high $\mathrm{CH}_{4}$ concentration are branch LFGVPs (B6, B9, B10, and B13). This could be due to the branch LFGEWs are far away from the main LCP; the air flow is difficult to move to these branch LFGEWs through the main LCP at the bottom of the landfill.

\subsection{Influence of the type of gas VPs on LFG concen- tration and temperature}

\subsubsection{The main gas VPM2}

Zone A (landfilling completed) contains four main LFGVPs: M1, M2, M3, and M4. Our analysis focuses on the main gas VP M2, where the height of the organic waste (approximately $20 \mathrm{~m}$ ) was the largest in the landfill site (see Figure 4).

Figure 7 shows the LFG concentration and temperature and the $\mathrm{CH}_{4} / \mathrm{CO}_{2}$ ratio at the exit of the main LFGVP $\mathrm{M} 2$. The air temperature fluctuated from $-20^{\circ} \mathrm{C}$ in winter to $25^{\circ} \mathrm{C}$ in summer. Though the air temperature was always below $0^{\circ} \mathrm{C}$ in the winter months, the high-temperature trend of LFG remained at $>40^{\circ} \mathrm{C}$ for more than 5 years before declining to $20^{\circ} \mathrm{C}$ in the most recent observation. This means that there was a continuous active aerobic condition around this LFGVP. Over the observation period, the $\mathrm{CH}_{4} / \mathrm{CO}_{2}$ ratio was below 1.0 (from 0.34 to 1.04). This shows that aerobization was active in this LFGVP, and the aerobic condition became dominant. The trend of this ratio increased slightly from the 1,200th day to the 2,450th day (from 2006 to January 2010) from the commencement of the landfilling operation and then declined gradually to less

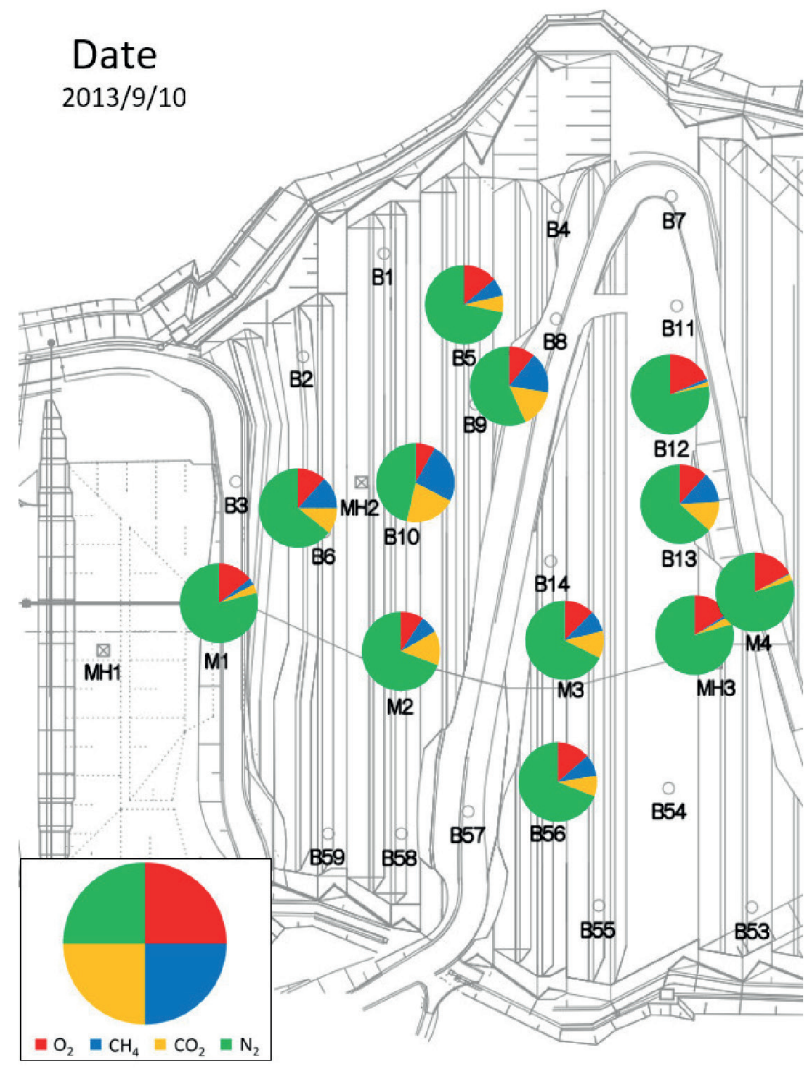

(a)

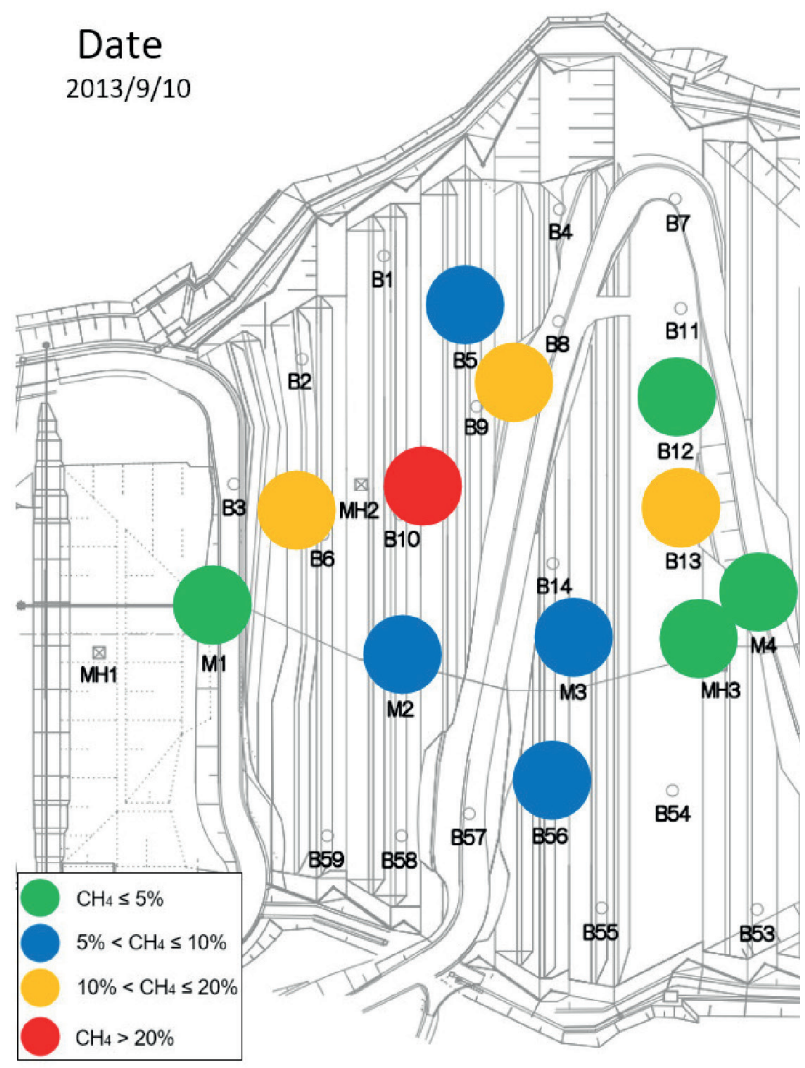

(b)

FIGURE 6: (a) Gas components and (b) ranking map of $\mathrm{CH}_{4}$ concentration at the exit of surveyed landfill gas venting pipes (Zone A) on September 10, 2013. 
than 0.5 by the 3,800th day (February 2014). The $\mathrm{CH}_{4}$ concentration at the exit ranged from $5 \%$ to $15 \%$. The $\mathrm{CH}_{4}$ concentration increased slightly, from $7 \%$ to $15 \%$, in the early observation and then decreased gradually to $5 \%$.

The findings reveal that, during the 7 years from December 2006 (3 years after the landfilling operation commenced) to February 2014, the $\mathrm{CH}_{4}$ concentration of the LFGVP M2 varied from 7\% to 15\% from December 2006 to August 2010 and then declined gradually. This decline may have been due to the gradual disappearance of organic waste. Obviously, the trend of reduction of LFG temperature, $\mathrm{CH}_{4}$ concentration, and the $\mathrm{CH}_{4} / \mathrm{CO}_{2}$ ratio may be useful indicators of the landfill stabilizing.

As the $\mathrm{CH}_{4}$ concentration data were recorded only at the exits of LFGVPs, the measured $\mathrm{CH}_{4}$ content could be diluted by air. However, even when we measured the $\mathrm{CH}_{4}$ and $\mathrm{O}_{2}$ concentrations since 2010 along the depths of the LFGVP M2, the $\mathrm{CH}_{4}$ concentration of this LFGVP was always less $20 \%$ from 2010 to 2013, and it then declined to below $10 \%$ in 2014 (Figure 8(a)).

The $\mathrm{CH}_{4}$ concentrations were always below $20 \%$ at all depths, whereas the $\mathrm{O}_{2}$ concentrations ranged from $\sim 1 \%$ to $\sim 15 \%$. The waste mass at the LFGVP M2 reached the designed elevation of $211 \mathrm{~m}$ in 2008. Most of the measurements were obtained in winter (January and February), and the surface of the landfill was covered with a thick lay- er of snow (the average annual snowfall is around $0.8 \mathrm{~m}$ ). This meant that it was impossible for air to migrate into the landfill body through the soil cover layers. However, the $\mathrm{O}_{2}$ concentrations inside the VP fluctuated around 8-15\%. During the summer and autumn months (August, September, and October), when there was no snow, the $\mathrm{O}_{2}$ concentrations dropped to below $5 \%$, and the $\mathrm{CH}_{4}$ concentrations increased to $20 \%$ (Figure $8(a, b)$ ). Such phenomena proved that the semi-aerobic mechanism was functioning. $\mathrm{O}_{2}$ is supplied into the waste mass from the LCPs at the bottom due to the buoyancy effect, which is a product of the temperature difference between the inside and outside of the landfill, and then it migrates to the waste layers near the LFGVPs. The more the temperature difference increases, the greater the amount of $\mathrm{O}_{2}$ drawn into the pipe network. As a result, aerobization happens strongly at the waste layers close to the LFGVPs.

The aim of semi-aerobic landfill is to promote aerobic biodegradation of organic wastes within the landfill. To assess the aerobization of the semi-aerobic landfill, LFG temperatures of LFGVPs should be measured. Figure 8(c) depicts the LFG temperature profiles of the main LFGVP M2. The LFG temperatures have been monitored since 2010 (7 years after the landfilling operation commenced).

The main LFGVP M2 showed the highest gas temperature of all the LFGVPs installed in the landfill area. The high-

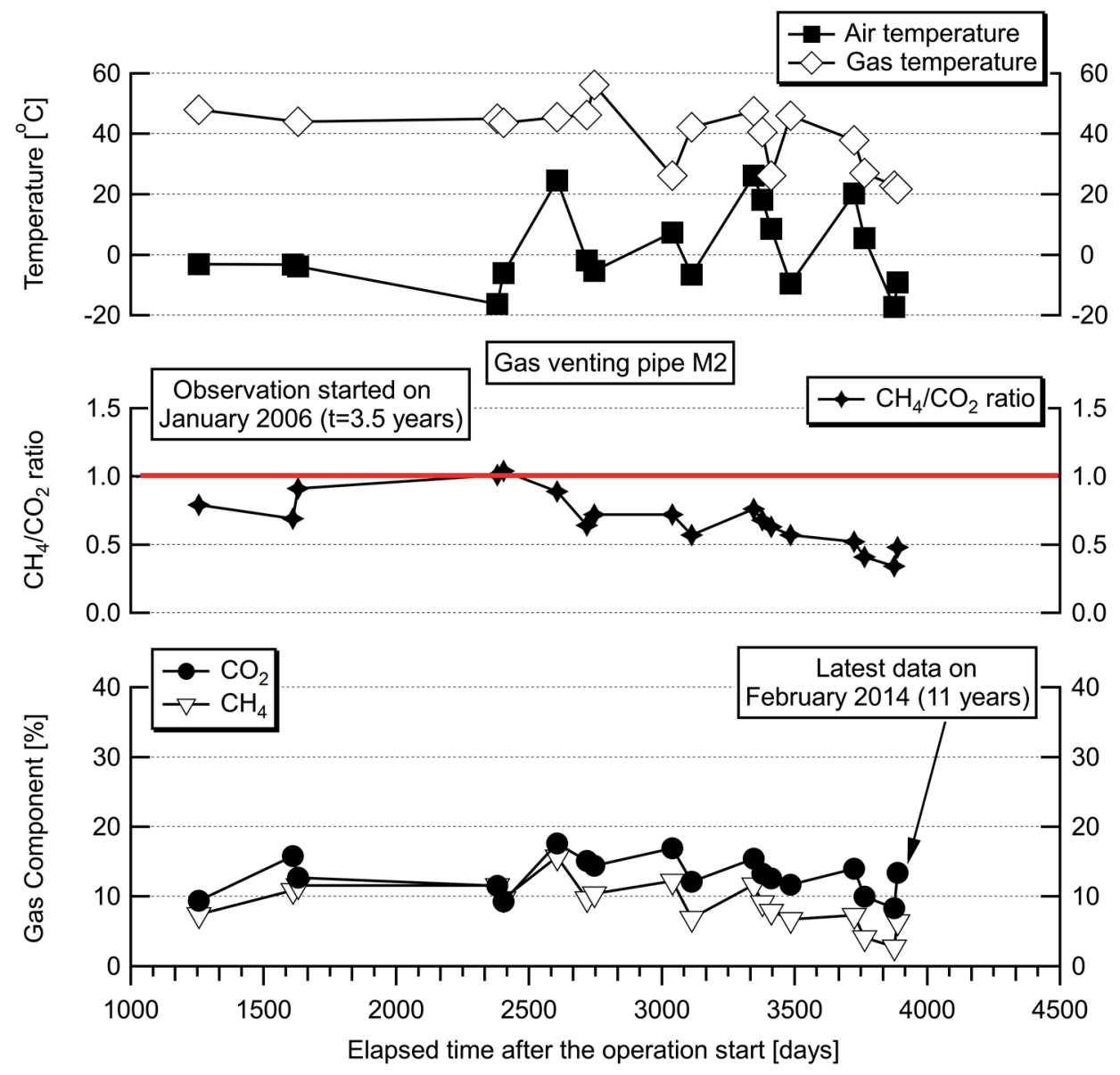

FIGURE 7: Landfill gas concentration and temperature and the $\mathrm{CH}_{4} / \mathrm{CO}_{2}$ ratio at the exit of the main landfill gas venting pipe $\mathrm{M} 2$. 


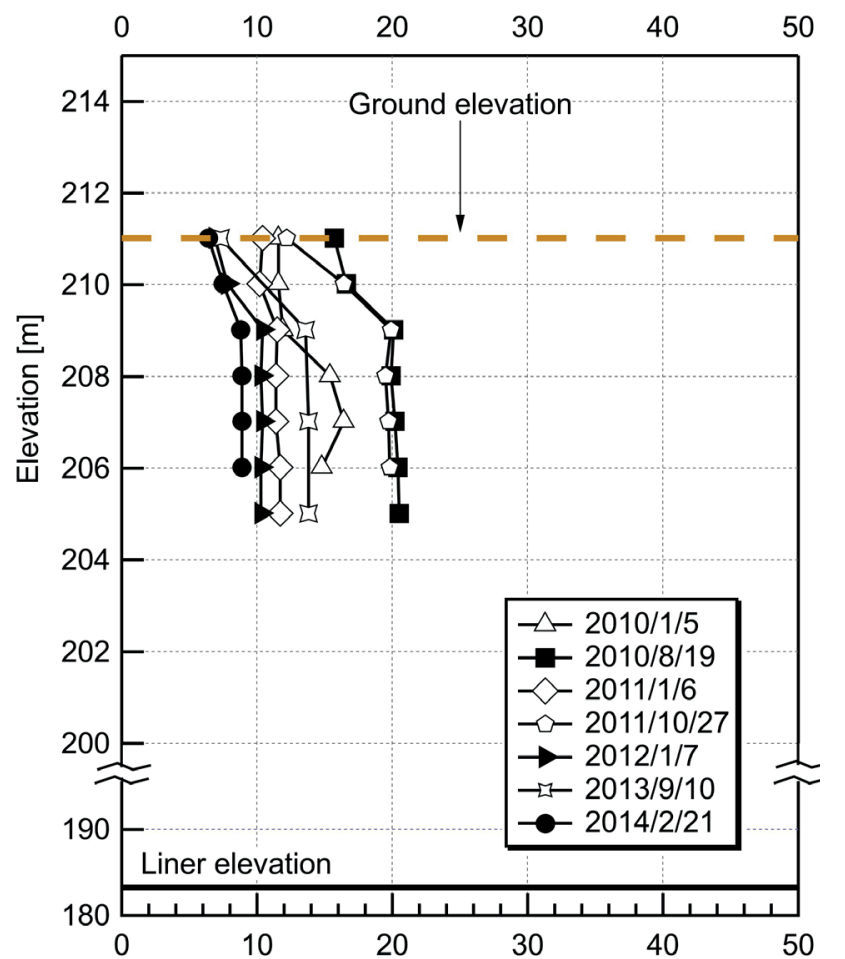

(a) $\quad \mathrm{CH}_{4}$ profile of the gas venting pipe $\mathrm{M} 2[\%]$

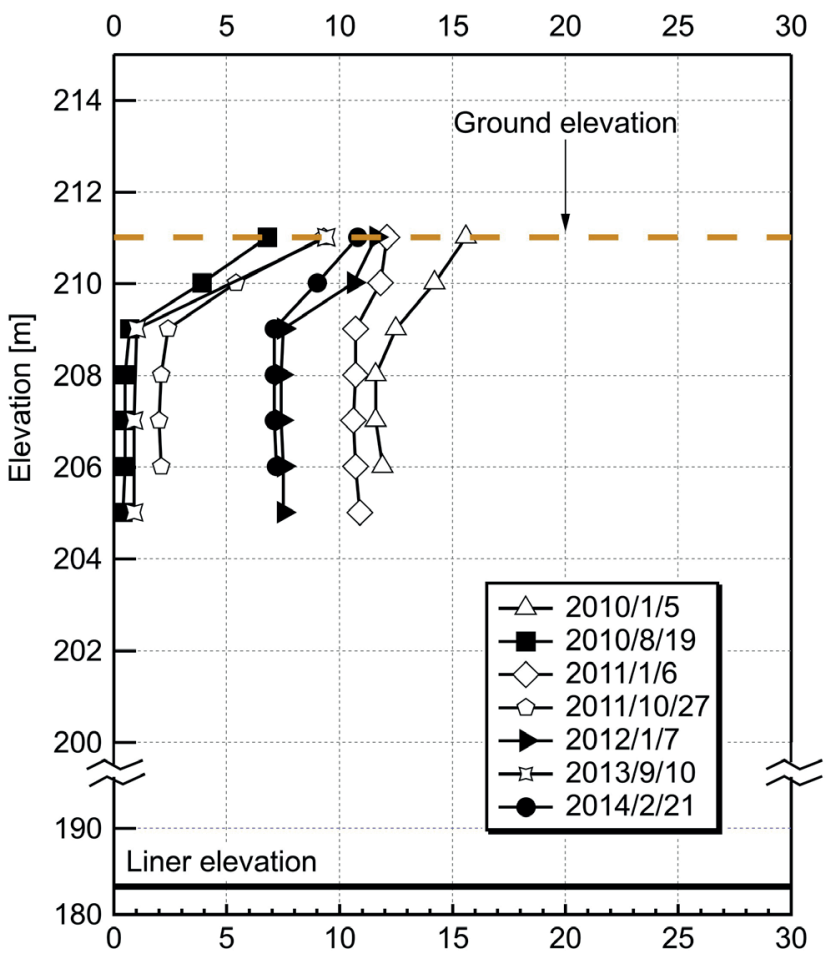

(b) $\mathrm{O}_{2}$ profile of the gas venting pipe $\mathrm{M} 2[\%]$

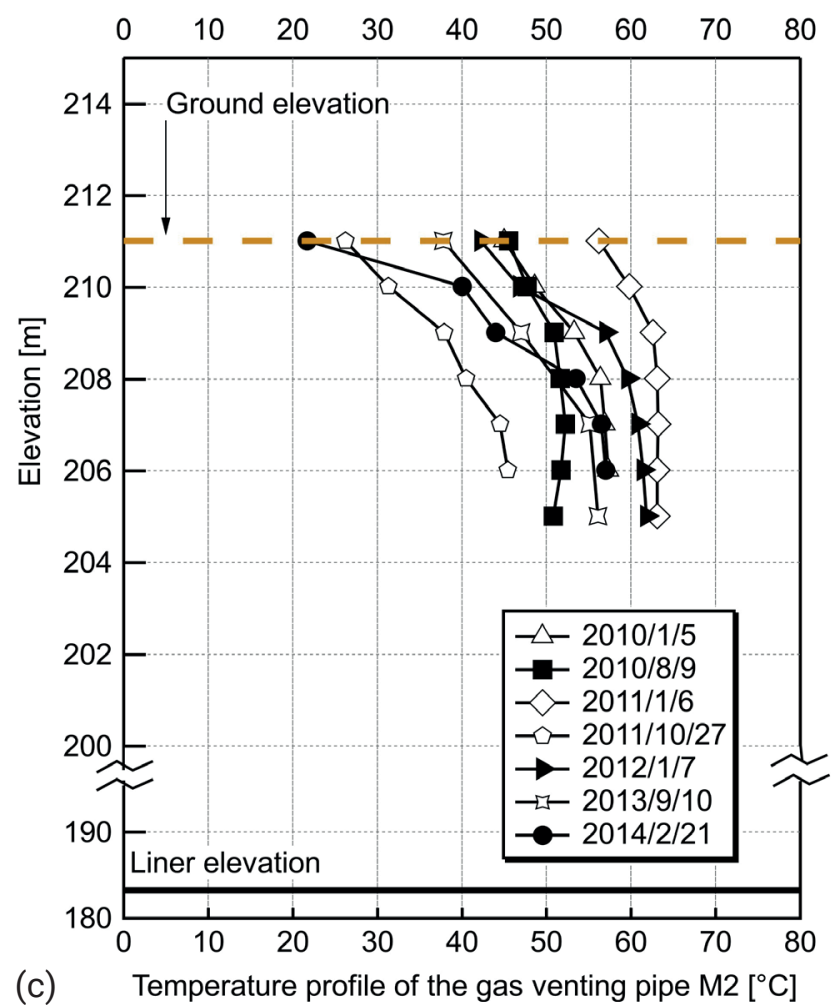

FIGURE 8: (a) $\mathrm{CH}_{4}$ concentration profile of the main landfill gas venting pipe $\mathrm{M}$; (b) $\mathrm{O}_{2}$ concentration profile of the main landfill gas venting pipe M2; (c) Temperature profile of the main LFG venting pipe M2.

est temperature recorded was $63.2^{\circ} \mathrm{C}$ at $-4 \mathrm{~m}$ depth in January 2011 , and the high-temperature trend continued until 2014. Figure 8(c) also indicates the elevated temperature of above $40^{\circ} \mathrm{C}$ from January 2010 to 2014 . The high temperatures were observed particularly in early January and
February. At that time, it was winter at the study site, and the average daily ambient temperature was from $-20^{\circ} \mathrm{C}$ to $-5^{\circ} \mathrm{C}$. The temperature difference between the inside and outside of the LFGVP was greater than $60^{\circ} \mathrm{C}$ (Figure 7). This affirms that the driving force of air flow in the semi-aerobic 
landfill increases in winter. Yanase et al. (2010) measured the rate of air flow into the LCP for 1 year and found a high flow rate in winter and no air flow in summer. That explains why our measurements recorded high temperatures in the landfill over the observation period.

\subsubsection{The branch gas VP B10}

The branch LFGVP B10 is located near the main LFGVP $M 2$. At this location, the height of the waste layers, including organic waste, was $\sim 10 \mathrm{~m}$. However, the average $\mathrm{CH}_{4}$ concentration of this branch LFGVP was highest (18.9\%) among the surveyed LFGVPs.

Figure 9 shows that the gas temperatures at the exits were affected by air temperatures. The LFG temperatures ranged from $7.1^{\circ} \mathrm{C}$ to $32.4^{\circ} \mathrm{C}$. Meanwhile, the $\mathrm{CH}_{4}$ concentrations ranged from $15 \%$ to $38 \%$ at the exit during 2,000 days (approximately 6 years) before declining to $0 \%$ at the most recent observation. Clearly, the $\mathrm{CH}_{4}$ concentration of the branch LFGVP B10 was 2-3 times higher than that of the main LFGVP M2 (see Figures 6, 7, and 12).

The ratio of $\mathrm{CH}_{4} / \mathrm{CO}_{2}$ ranged from 0.8 to 1.2 for 6 years before decreasing to 0 . The fact that the LFG concentration was 0 in the most recent observation could be due to the disappearance of organic waste. In this case, the anaerobic condition could become more dominant than the aerobic condition.

Figure $10(a, b)$ shows the $\mathrm{CH}_{4}$ and $\mathrm{O}_{2}$ concentration profiles of the branch LFGVP B10. The $\mathrm{CH}_{4}$ concentrations ranged from $20 \%$ to $45 \%$, whereas the $\mathrm{O}_{2}$ concentrations ranged, approximately, from $0 \%$ to $10 \%$. Apart from the measurement obtained in August 2010, the $\mathrm{O}_{2}$ concentration reached $0 \%$ and the $\mathrm{CH}_{4}$ concentration reached $45 \%$. In other measurements, the $\mathrm{CH}_{4}$ concentration fluctuated from $20 \%$ to $38 \%$, whereas the $\mathrm{O}_{2}$ concentration ranged from $3 \%$ to $10 \%$, and the temperature ranged from $10^{\circ} \mathrm{C}$ to $30^{\circ} \mathrm{C}$ [Figure $10(\mathrm{c})$ ]. These indicators reveal that the anaerobic condition became dominant.

Figure 10(c) depicts the temperature profile of the branch LFGVP B10. The highest temperature was $40^{\circ} \mathrm{C}$ at $0 \mathrm{~m}$ depth (at ground elevation) in September 2012, and a high-temperature trend was recorded in August 2010, when the gas temperature ranged from $22^{\circ} \mathrm{C}$ to $32^{\circ} \mathrm{C}$, with the highest value being at ground level. In general, the shape of the gas temperature line of this LFGVP was different from the shape of the temperature line of the LFGVP M2 (see Figure 8 ). In this case, as the $\mathrm{O}_{2}$ concentration remained between $3 \%$ and 10\% inside the LFGVP [Figure 10(b)], it may be that the organic wastes near the LFGVP were exhausted and the $\mathrm{CH}_{4}$ moved to the LFGVP from distant areas where anaerobic conditions existed.

4.2.3 The average values of the gas temperature, $\mathrm{CH}_{4}$ concentration and the ratio of $\mathrm{CH}_{4} / \mathrm{CO}_{2}$

Figure 11 shows the average values of the gas temperatures, the $\mathrm{CH}_{4}$ concentrations, and the $\mathrm{CH}_{4} / \mathrm{CO}_{2}$ ratios at the exits of the surveyed LFGVPs (from December 2006 to
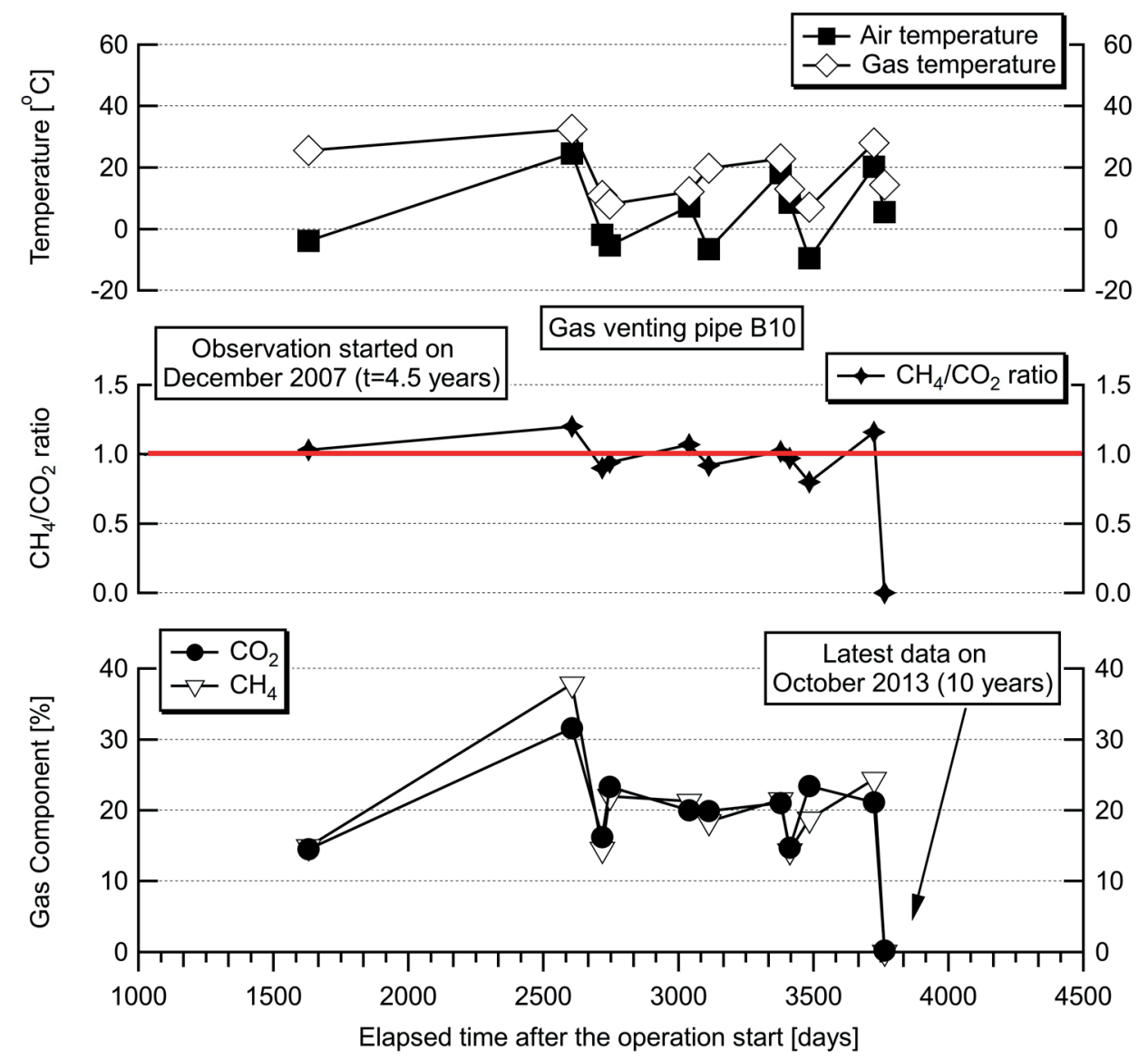

FIGURE 9: Landfill gas concentration and temperature and the $\mathrm{CH}_{4} / \mathrm{CO}_{2}$ ratio at the exit of the branch landfill gas venting pipe B10. 


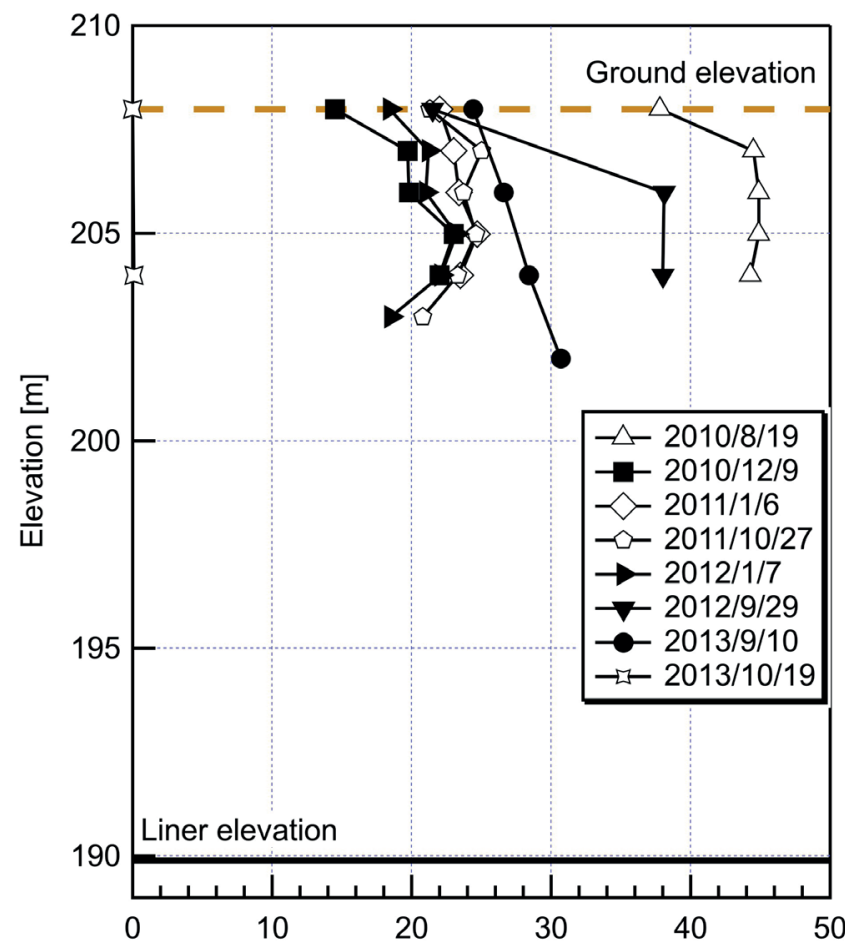

(a) $\mathrm{CH}_{4}$ profile of the branch gas venting pipe $\mathrm{B} 10$ [\%]

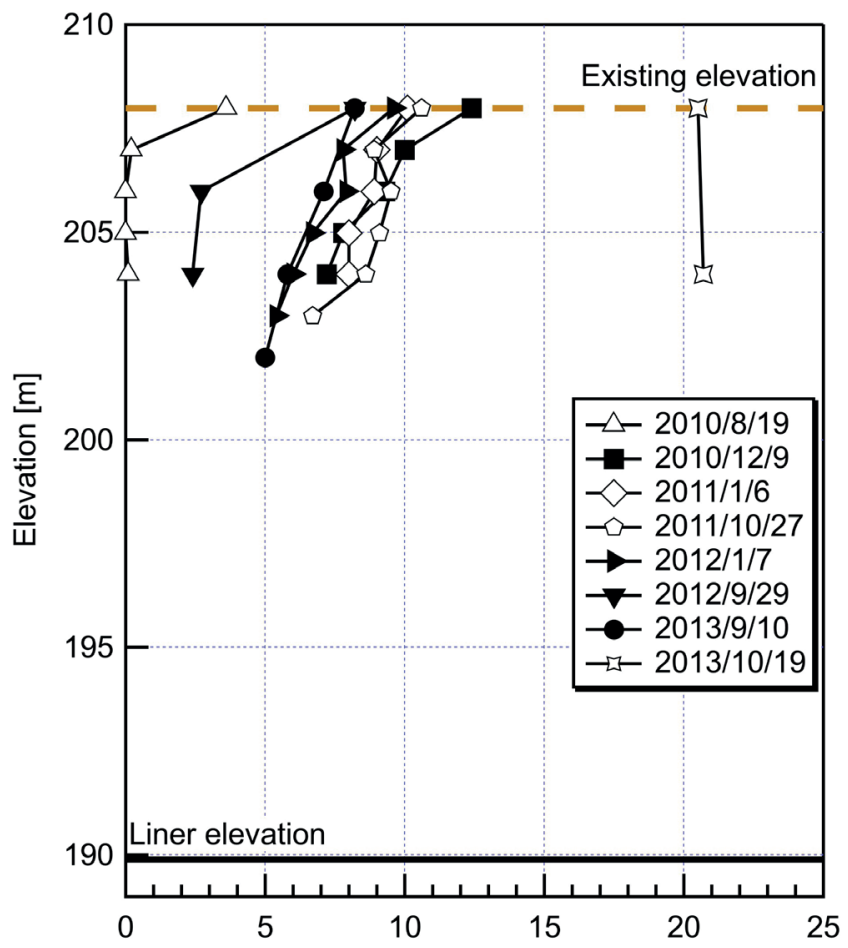

(b) $\mathrm{O}_{2}$ profile of the branch gas venting pipe $\mathrm{B} 10$ [\%]

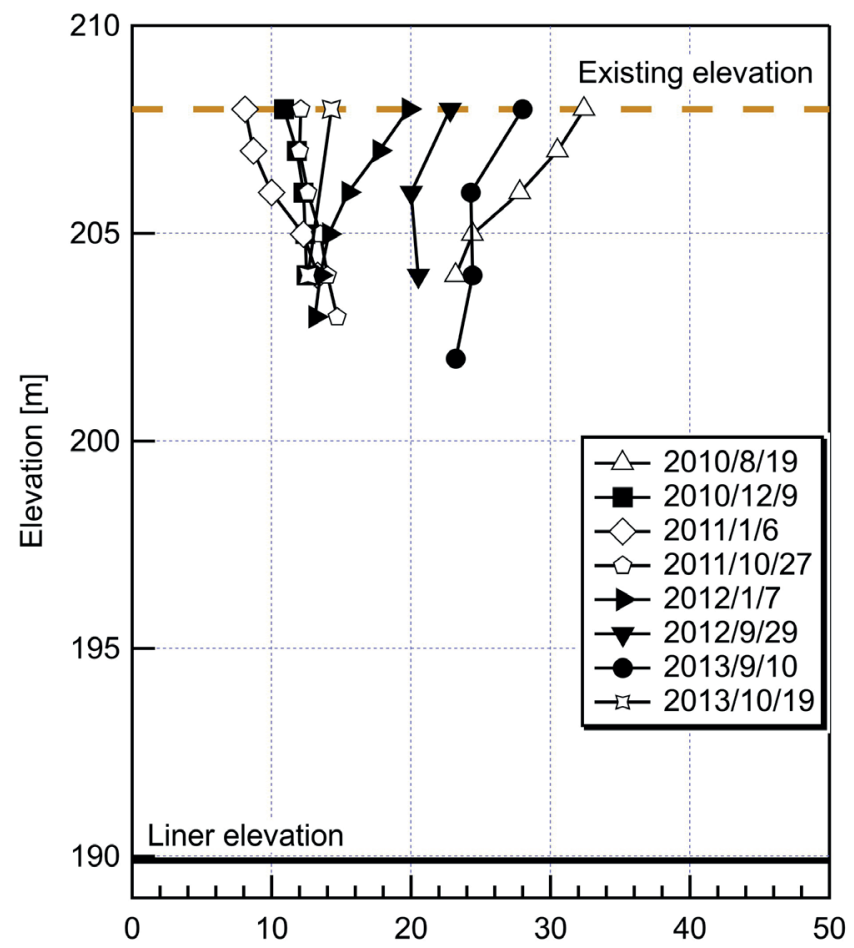

(c) Temperature profile of the branch gas venting pipe $\mathrm{B} 10\left[{ }^{\circ} \mathrm{C}\right]$

FIGURE 10: (a) $\mathrm{CH}_{4}$ concentration profile of the branch landfill gas venting pipe B10; (b) $\mathrm{O}_{2}$ concentration profile of the branch landfill gas venting pipe B10; (c) Temperature profile of the branch landfill gas venting pipe B10.

February 2014). The average LFG temperatures of the main LFGVPs (M1, M2, M3, and M4) were higher than those of the branch LFGVPs. The average $\mathrm{CH}_{4}$ concentrations of the main LFGVPs were below $10 \%$. In particular, the $\mathrm{CH}_{4} / \mathrm{CO}_{2}$ ratios of the main LFGVPs were below 0.8 , whereas the $\mathrm{CH}_{4} /$
$\mathrm{CO}_{2}$ ratios of the branch LFGVPs ranged from 0.9 to 1.1 . This means that there was more effective aerobic biodegradation at the main LFGVPs than that the branch LFGVPs.

Although the branch LFGVPs B1, B2, and B3 showed average $\mathrm{CH}_{4} / \mathrm{CO}_{2}$ ratios of below 0.4 and average $\mathrm{CH}_{4}$ 
(a) Average temperature at the exit of surveyed gas venting pipes (from Dec 2006 to Feb 2014)

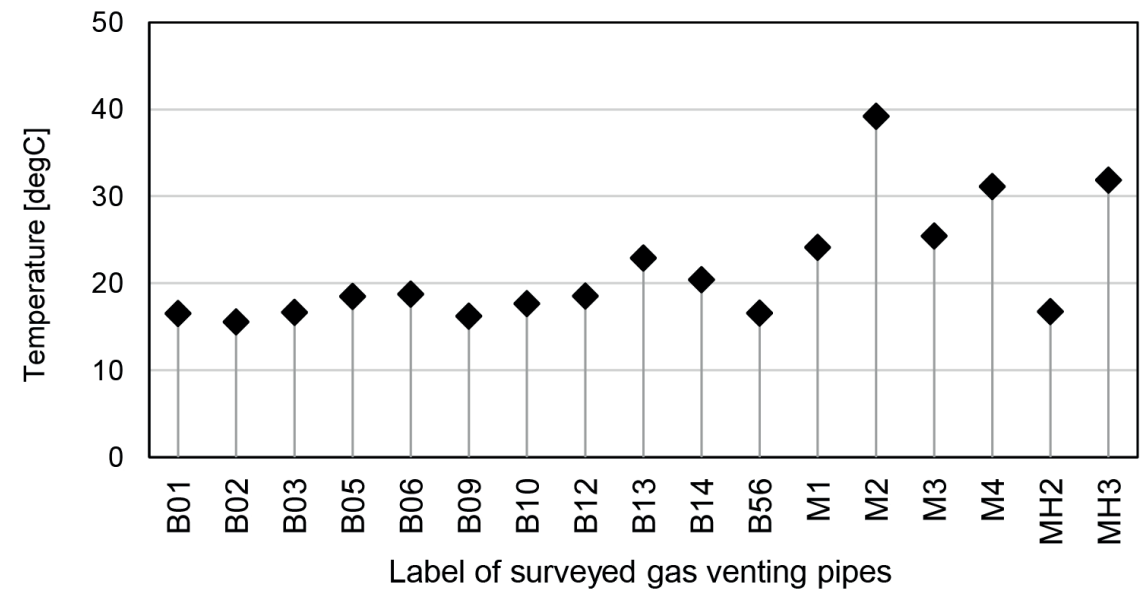

(b) Average methane gas concentration at the exit of surveyed

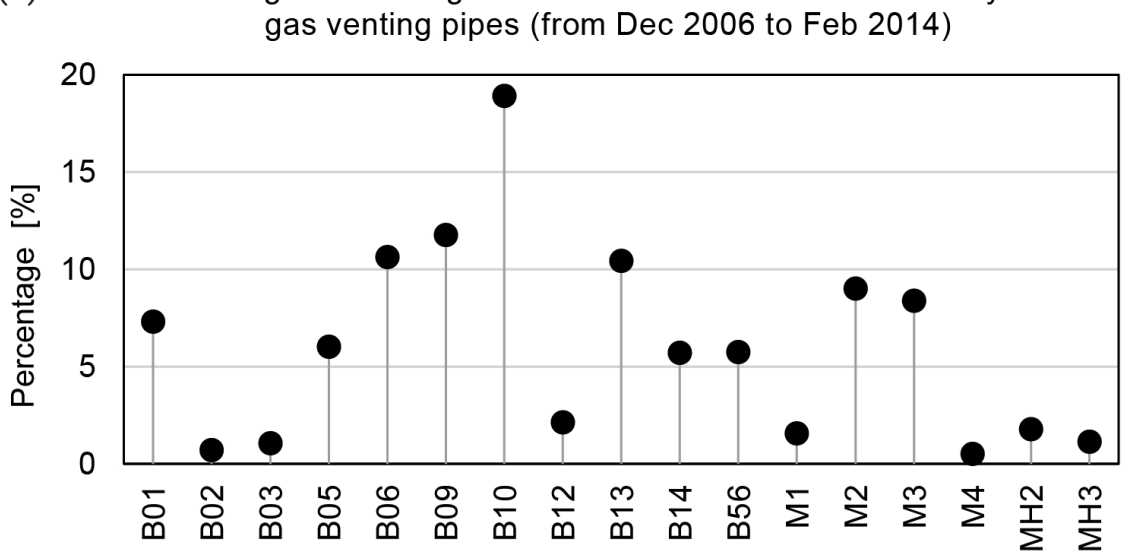

Label of surveyed gas venting pipes

(c) The average ratio of $\mathrm{CH} 4 / \mathrm{CO} 2$ at the exit of surveyed gas venting pipes (from Dec 2006 to Feb 2014)

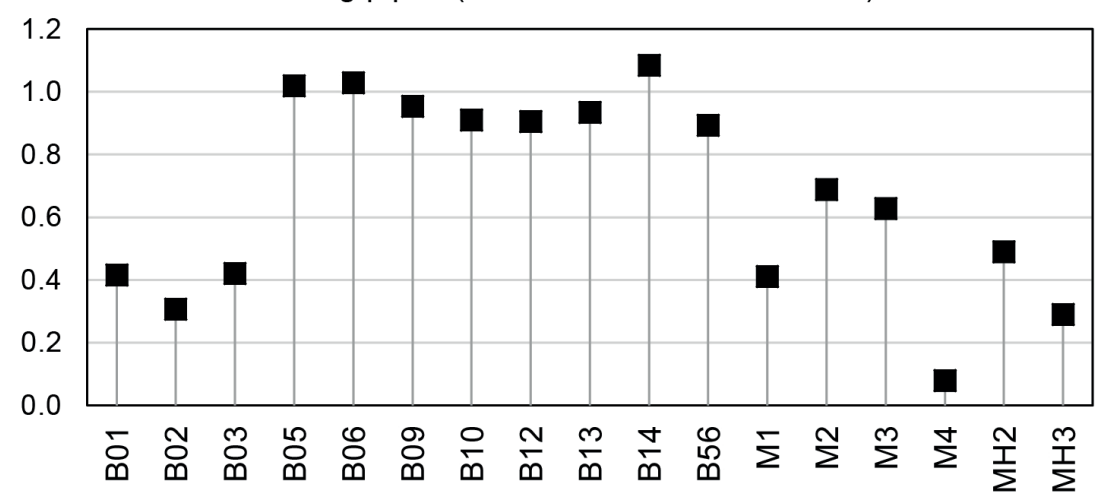

Label of surveyed gas venting pipes

FIGURE 11: The average values of (a) the gas temperature and (b) $\mathrm{CH}_{4}$ concentrations and (c) the $\mathrm{CH}_{4} / \mathrm{CO}_{2}$ ratio at the exit of the surveyed landfill gas venting pipes during the period from December 2006 to February 2014.

concentrations below $7 \%$, the average LFG temperatures were below $20^{\circ} \mathrm{C}$. Thus, it may be that the anaerobic condition was still dominant. Another reason could be due to the amount of organic matter within the waste mass exhausted.

\section{CONCLUSIONS}

In this study, we surveyed several important indicators, including the LFG temperature and concentration and ratio of $\mathrm{CH}_{4}$ to $\mathrm{CO}_{2}$, of an operating semi-aerobic landfill at full 
scale. Our observations indicated that the passive aeration happened effectively. The aerobic condition occurred around the main LFGVPs. The highest LFG temperature was over $60^{\circ} \mathrm{C}$ and remained above $40^{\circ} \mathrm{C}$ for over 5 years. The average $\mathrm{CH}_{4}$ concentrations were below $15 \%$. These above analyses also showed that high temperature and the $\mathrm{CH}_{4} / \mathrm{CO}_{2}$ ratio less than 1.0 potentially are useful indicators of the type of landfill processes. They can help landfill operators realize the predominance of aerobic biodegradation within the landfill. Oxygen $\left(\mathrm{O}_{2}\right)$ is supplied naturally into the waste mass without the need for a blower, promoting aerobization within the landfill through the buoyancy effect. This leads to reducing significantly the costs of construction and operation. The aerobic biodegradation performance of the branch LFGVPs was not as efficient as the main LFGVPs.

Although our study focuses only on the analysis of LFG components and LFG temperatures, these are useful indicators that can be measured easily on-site to identify the aerobic condition of operating semi-aerobic landfills. Besides analyzing the leachate quality, monitoring the LFG concentration and temperature periodically is required to detect the sudden rise in $\mathrm{CH}_{4}$ concentrations in semi-aerobic landfills. This monitoring should play a key role in evaluating the passive aeration performance of semi-aerobic landfills.

This paper is the first step in a series of our researches. We will develop the research in further works by conducting the coupling analysis. Next steps, the numerical simulations will be used for modeling the gas production, temperature distribution, gas concentrations and we will compare the numerical simulations with the real data and evaluate the gas and heat transport phenomena within the semi-aerobic landfill.

\section{ACKNOWLEDGMENTS}

The authors would like to thank the Asahikawa Municipality Government and the Yoshino semi-aerobic landfill operation management team for their valuable supports.

\section{REFERENCES}

Ahmadifar, M., Sartaj, M., Abdallah, M., 2016. Investigating the performance of aerobic, semi-aerobic, and anaerobic bioreactor landfills for MSW management in developing countries. J Mater Cycles Waste Manag 18, 703-714. https://doi.org/10.1007/s10163-0150372-0

Antonis, M., Haris, K., 2009. The concept of sustainable landfills. Presented at the 2009 World Waste Congress, Lisbon.

ATSDR, 2001. Chapter 2: Landfill Gas Basics. Landfill Gas Primer, an Overview for Environmental Health Professionals, pp. 3-14.

Barlaz, M.A., Bryan, F.S., Francis, L.D.L.R.I., 2010. Anaerobic Biodegradation of Solid Waste, in: Environmental Microbiology, 2nd Ed. Wiley-Blackwell, Hoboken, New Jersey, pp. 281-300.

Benson, C.H., 2017. Characteristics of Gas and Leachate at an Elevated Temperature Landfill, in: Geotechnical Frontiers 2017. Presented at the Geotechnical Frontiers 2017, American Society of Civil Engineers, Orlando, Florida, pp. 313-322. https://doi. org/10.1061/9780784480434.034

Bouazza, A., Nahlawi, H., Aylward, M., 2011. In Situ Temperature Monitoring in an Organic-Waste Landfill Cell. J. Geotech. Geoenviron. Eng. 137, 1286-1289. https://doi.org/10.1061/(ASCE)GT.19435606.0000533
Cooney, C.L., Wang, D.I.C., Mateles, R.I., 1969. Measurement of heat evolution and correlation with oxygen consumption during microbial growth. Biotechnol. Bioeng. 11, 269-281. https://doi. org/10.1002/bit.260110302

Cossu, R., 2012. The environmentally sustainable geological repository: The modern role of landfilling. Waste Management 32, 243244. https://doi.org/10.1016/j.wasman.2011.11.005

Cossu, R., 2009. From triangles to cycles. Waste Management 29, 2915-2917. https://doi.org/10.1016/j.wasman.2009.09.002

Cossu, R., 2005. The Sustainable Landfilling Concept, in: Proceedings Sardinia 2005. Presented at the Tenth International Waste Management and Landfill Symposium, 3-7 October 2005, S. Margherita di Pula, Cagliari, Italy, p. 9.

Cossu, R., Morello, L., Raga, R., Cerminara, G., 2016. Biogas production enhancement using semi-aerobic pre-aeration in a hybrid bioreactor landfill. Waste Management 55, 83-92. https://doi. org/10.1016/j.wasman.2015.10.025

FEMA, 2002. Landfill Fires Their Magnitude, Charaacteristics, and Mitigation. https://www.usfa.dhs.gov/downloads/pdf/publications/fa -225.pdf

Grossule, V., Lavagnolo, M.C., 2017. Innovative Semi-aerobic Landfill Management in Tropical Countries, in: Proceedings Sardinia 2017. Presented at the Sixteenth International Waste Management and Landfill Symposium, 2 - 6 October 2017, CISA, S. Margherita di Pula, Cagliari, Italy, p. 14.

Grossule, V., Morello, L., Cossu, R., Lavagnolo, M.C., 2018. Bioreactor Landfills: Comparison and kinetics of the Different Systems. DETRITUS - Multidisciplinary Journal for Waste Resources \& Residues 03, 100-113. https://doi.org/10.31025/2611-4135/2018.13703

Hanashima, M., Yamasaki, K., Kuroki, T., Onishi, K., 1981. Heat and gas flow analysis in semiaerobic landfill. Journal of the Environmental Engineering Division 107, 1-9.

Hirata, O., Matsufuji, Y., Tachifuji, A., Yanase, R., 2012. Waste stabilization mechanism by a recirculatory semi-aerobic landfill with the aeration system. J Mater Cycles Waste Manag 14, 47-51. https:// doi.org/10.1007/s10163-011-0036-7

Hrad, M., Gamperling, O., Huber-Humer, M., 2013. Comparison between lab- and full-scale applications of in situ aeration of an old landfill and assessment of long-term emission development after completion. Waste Management 33, 2061-2073. https://doi. org/10.1016/j.wasman.2013.01.027

Huang, Q., Yang, Y., Pang, X., Wang, Q., 2008. Evolution on qualities of leachate and landfill gas in the semi-aerobic landfill. Journal of Environmental Sciences 20, 499-504. https://doi.org/10.1016/ S1001-0742(08)62086-0

IPCC, 2006. IPCC guidelines for national greenhouse gas inventories. Prepared by Intergovernmental Panel on Climate Change (IPCC).

Ishigaki, T., Hirata, O., Oda, T., Wangyao, K., Chiemchaisri, C., Towprayoon, S., Lee, D.-H., Yamada, M., 2011. Greenhouse Gas Emission from Solid Waste Disposal Sites in Asia, in: Integrated Waste Management. InTech.

Jafari, N.H., Stark, T.D., Thalhamer, T., 2017. Spatial and temporal characteristics of elevated temperatures in municipal solid waste landfills. Waste Management 59, 286-301. https://doi.org/10.1016/j. wasman.2016.10.052

Jeong, S., Nam, A., Yi, S.-M., Kim, J.Y., 2015. Field assessment of semi-aerobic condition and the methane correction factor for the semi-aerobic landfills provided by IPCC guidelines. Waste Management 36, 197-203. https://doi.org/10.1016/j.wasman.2014.10.020

Kim, H.-J., Yoshida, H., Matsuto, T., Tojo, Y., Matsuo, T., 2010. Air and landfill gas movement through passive gas vents installed in closed landfills. Waste Management 30, 465-472. https://doi. org/10.1016/j.wasman.2009.10.005

Martin, J.W., Stark, T.D., Thalhamer, T., Gerbasi-Graf, G.T., Gortner, R.E., 2013. Detection of Aluminum Waste Reactions and Waste Fires. J. Hazard. Toxic Radioact. Waste 17, 164-174. https://doi. org/10.1061/(ASCE)HZ.2153-5515.0000171

Matsufuji, Y., Kobayashi, H., Tanaka, A., Ando, S., Kawabata, T., Hanashima, M., 1996. Generation of greenhouse effect gases by different landfill types and methane gas control, in: Proceedings of 7th ISWA International Congress and Exhibition, Yokohama, Japan. Yokohama, Japan, pp. 230-237.

Matsufuji, Y., Tachifuji, A., 2007. The history and status of semi-aerobic landfills in Japan and Malaysia, in: Landfill Aeration, IWWG Monograph. CISA, pp. 109-116. 
Matsuto, T., Zhang, X., Matsuo, T., Yamada, S., 2015. Onsite survey on the mechanism of passive aeration and air flow path in a semi-aerobic landfill. Waste Management 36, 204-212. https:// doi.org/10.1016/j.wasman.2014.11.007

Morello, L., Raga, R., Lavagnolo, M.C., Pivato, A., Ali, M., Yue, D., Cossu, R., 2017. The S.An.A. ${ }^{\circledR}$ concept: Semi-aerobic, Anaerobic, Aerated bioreactor landfill. Waste Management 67, 193-202. https://doi. org/10.1016/j.wasman.2017.05.006

Pirt, S.J., 1978. Aerobic and anaerobic microbial digestion in waste reclamation. Journal of Applied Chemistry and Biotechnology 28, 232-236.

Rees, J.F., 1980. Optimisation of methane production and refuse decomposition in landfills by temperature control. J. Chem. Technol. Biotechnol. 30, 458-465. https://doi.org/10.1002/jctb.503300158

Ritzkowski, M., Heyer, K.-U., Stegmann, R., 2006. Fundamental processes and implications during in situ aeration of old landfills. Waste Management 26, 356-372. https://doi.org/10.1016/j.wasman.2005.11.009

Ritzkowski, M., Stegmann, R., 2012. Landfill aeration worldwide: Concepts, indications and findings. Waste Management 32, 14111419. https://doi.org/10.1016/j.wasman.2012.02.020

Shimaoka, T., Matsufuji, Y., Hanashima, M., 2000. Characteristic and Mechanism of Semi-Aerobic Landfill on Stabilization of Solid Waste. Presented at the Intercontinental Landfill Research Symposium.

Stegmann, R., Ritzkowski, M., 2007. Landfill Aeration, IWWG Monograph. CISA.

Theng, L.C., Matsufuji, Y., Hassan, M.N., 2005. Implementation of the semi-aerobic landfill system (Fukuoka method) in developing countries: A Malaysia cost analysis. Waste Management 25, 702711. https://doi.org/10.1016/j.wasman.2005.01.008
Wu, X., Yue, B., Huang, Q., Wang, Q., Lin, Y., Zhang, W., Yan, Z., 2017. Spatio-temporal variation of landfill gas in pilot-scale semi-aerobic and anaerobic landfills over 5 years. Journal of Environmental Sciences 54, 288-297. https://doi.org/10.1016/j.jes.2016.09.015

Yanase, R., Matsufuji, Y., Michihiro, S., Tashiro, T., Shigeo, N., 2010. Study of the air inflow velocity in the semi aerobic landfill site (in Japanese), in: Proceedings of the 21th Annual Conference of the Japan Society of Material Cycles and Waste Management. https:// doi.org/10.14912/jsmcwm.21.0.260.0

Yang, Yangfei, Yue, B., Yang, Yu, Huang, Q., 2012. Influence of semi-aerobic and anaerobic landfill operation with leachate recirculation on stabilization processes. Waste Manag Res 30, 255-265. https:// doi.org/10.1177/0734242X11413328

Yesiller, N., Hanson, J.L., Yee, E.H., 2015. Waste heat generation: A comprehensive review. Waste Management 42, 166-179. https:// doi.org/10.1016/j.wasman.2015.04.004

Yesiller, N., Hanson, J.L., Yoshida, H., 2011. Landfill Temperatures under Variable Decomposition Conditions, in: Geo-Frontiers 2011. Presented at the Geo-Frontiers Congress 2011, American Society of Civil Engineers, Dallas, Texas, United States, pp. 1055-1065. https://doi.org/10.1061/41165(397)108

Yoshida, H., Rowe, R.K., 2003. Consideration of Landfill Liner Temperature, in: Proceedings Sardinia 2003,. Presented at the Ninth International Waste Management and Landfill Symposium, 6-10 October, CISA, Environmental Sanitary Engineering Centre, Italy, S. Margherita di Pula, Cagliari, Italy.

Zhang, X., Matsuto, T., 2013. Assessment of internal condition of waste in a roofed landfill. Waste Management 33, 102-108. https://doi. org/10.1016/j.wasman.2012.08.008 